\title{
Analisis Penerimaan Yoghurt Sari Almond dengan Penambahan Kurma
}

\author{
The Acceptance Analysis of Almond Extract Yogurt with the Addition of Dates
}

\section{Anisa Firdatama, Esteria Priyanti*}

\author{
Program Studi Seni Kuliner, Akademi Kesejahteraan Sosial Ibu Kartini, Jl. Sultan Agung, No. 77, Semarang \\ 50232, Indonesia
}

*Penulis korespondensi: Esteria Priyanti, e-mail: esteria@ aksibukartini.ac.id

Tanggal submisi: 8 April 2021; Tanggal penerimaan: 21 Juli 2021; Tanggal publikasi: 23 Agustus 2021

\begin{abstract}
The purpose of this study was to determine the acceptance of almond extract yoghurt mixed with dates. This research was divided into 3 stages. The first stage included preparing ingredients and equipment and preparing formulas for almond extract yoghurt with dates. The second stage involved adding dates into almond extract yoghurt. The third stage was the implementation of the hedonic test and the ranking test. The percentage of adding dates in the production of almond extract yoghurt was as much as 10, 20, and 30\% of the weight of the almond extract, respectively. Thirty (30) untrained panelists participated in the hedonic and rating tests. The nonparametric analysis Kruskal Wallis test and the Mann-Whitney further test were used to examine the data. The Kruskal Wallis test showed significant differences in taste, aroma, texture, and color between almond extract yoghurt with dates. The Mann-Whitney test showed that the taste, aroma, viscosity, and color of almond extract yoghurt with the addition of dates as much as $10 \%$ were significantly different from $20 \%$ and $30 \%$. It can be concluded that the addition of dates can increase the acceptance of the taste, aroma, viscosity, and color of almond extract yoghurt.
\end{abstract}

Keywords: Almond extract; dates; yoghurt; acceptance.

(C) The Authors. Publisher Universitas Pattimura. Open access under CC-BY-SA license.

\begin{abstract}
ABSTRAK
Tujuan dari penelitian ini yaitu mengetahui penerimaan yoghurt sari almond dengan penambahan kurma. Penelitian ini terdiri atas tiga tahap. Tahap pertama meliputi persiapan bahan dan peralatan serta penyusunan formula yoghurt sari almond dengan penambahan kurma. Tahap kedua yaitu proses pembuatan yoghurt sari almond dengan penambahan kurma. Tahap ketiga yaitu pelaksanaan uji hedonik dan uji peringkat. Persentase penambahan kurma pada pembuatan yoghurt sari almond yaitu sebanyak 10\%, 20\%, dan 30\% dari berat sari almond. Uji hedonik dan uji peringkat melibatkan 30 panelis tidak terlatih. Data dianalisis menggunakan analisis nonparametrik uji Kruskal Wallis dan uji lanjut Mann-Whitney. Hasil uji Kruskal Wallis menunjukkan penambahan kurma memberikan perbedaan yang nyata pada penerimaan rasa, aroma, kekentalan dan warna yoghurt sari almond. Uji lanjut Mann-Whitney menunjukkan bahwa rasa, aroma, kekentalan dan warna dari yoghurt sari almond dengan penambahan kurma sebanyak $10 \%$ berbeda nyata dengan $20 \%$ dan 30\%. Dapat disimpulkan bahwa penambahan kurma dapat meningkatkan penerimaan rasa, aroma, kekentalan dan warna yoghurt sari almond.
\end{abstract}

Kata kunci: Kurma; penerimaan; sari almond; yoghurt

(C) Penulis. Penerbit Universitas Pattimura. Akses terbuka dengan lisensi CC-BY-SA. 


\section{PENDAHULUAN}

Yoghurt merupakan salah satu minuman kesehatan yang terbuat melalui proses fermentasi susu. Yoghurt disebut minuman kesehatan karena mengandung bakteri baik yang sangat menguntungkan bagi saluran pencernaan. Bakteri tersebut adalah Lactobacillus bulgaricus dan Streptococcus thermophilus. Saat proses fermentasi, L. bulgaricus dan $S$. thermophilus akan mengubah gula dan laktosa yang terdapat di dalam susu menjadi asam laktat. Asam laktat inilah yang menghasilkan rasa asam pada produk yoghurt (Syainah et al., 2014). Proses fermentasi juga dapat menurunkan kadar laktosa, sehingga konsumsi yoghurt dapat menjadi salah satu solusi alternatif bagi penderita laktosa intoleran (Nurminabari, 2018).

Saat ini telah banyak dikembangkan produk yoghurt berbahan dasar sari kacang-kacangan, salah satunya yaitu yoghurt sari almond. Yoghurt sari almond dapat dikombinasikan dengan bahan lain, salah satunya yaitu buah kurma. Telah banyak penelitian yang mengembangkan produk yoghurt sari almond dan yoghurt kurma. Beberapa hasil penelitian terkait yoghurt sari almond antara lain penelitian dari Lubis dan Anjani (2016) tentang yoghurt sari almond dengan penambahan sari buah jeruk. Hasil penelitian tersebut menyatakan produk dengan formula $20 \%$ sari almond dan $8 \%$ sari buah jeruk memiliki aktivitas antioksidan tertinggi dibanding formula lainnya yaitu sebesar $49 \%$. Penelitian lain dari Rusilawati (2019) menghasilkan formula yoghurt sari almond terbaik. Formula sari almond terbaik menggunakan sari almond dengan perbandingan kacang almond dan air sebesar 2:1. Selain itu, terdapat penelitian dari Nath et al. (2020) menyatakan bahwa yoghurt dengan penambahan buah-buahan dan sari almond dapat memperbaiki karakteristik sensori, kandungan gizi (karbohidrat, lemak dan protein), serta kandungan senyawa fenolik dan flavonoid dari yoghurt.

Adapun hasil penelitian terkait yoghurt sari kurma antara lain penelitian dari Retnowati dan Kusnadi (2014) tentang minuman probiotik sari buah kurma. Hasil penelitian tersebut yaitu produk dengan atribut organoleptik terbaik adalah produk yang menggunakan perbandingan buah kurma dan air sebanyak 1:5 dengan perlakuan lama fermentasi 20 jam. Penelitian lain dari Arisanti dan Islamiyah (2017) tentang fruitghurt (yoghurt yang terbuat dari sari buah) dengan penambahan sari kurma. Fruitghurt dengan penambahan sari kurma sebanyak $15 \%$ merupakan produk yang menghasilkan kadar total asam laktat tertinggi. Penambahan sari kurma sebanyak $25 \%$ menghasilkan kadar vitamin $\mathrm{C}$ dan protein tertinggi. Selanjutnya, penelitian dari Purwanto et al. (2018) tentang yoghurt sari kedelai dengan penambahan jus kurma. Produk yang paling disukai yaitu dengan formula $10 \%$ sari kedelai dan $80 \%$ jus kurma.

Berdasarkan latar belakang tersebut, masih sedikit yang melakukan pengembangan produk yoghurt dengan kombinasi antara sari almond dan kurma. Oleh sebab itu, peneliti melakukan pengembangan produk yoghurt sari almond dengan penambahan kurma. Penelitian ini menggunakan kurma yang dihancurkan bersama dengan sari almond, kemudian disaring dan menghasilkan filtrat. Filtrat tersebut kemudian ditambahkan bahan lainnya untuk dijadikan yoghurt. Alasan pemilihan kurma karena kurma dapat menghasilkan rasa manis yang alami (Astrini et al., 2017). Penambahan kurma pada pembuatan yoghurt sari almond diharapkan dapat menghasilkan inovasi produk pangan baru yang dapat diterima oleh masyarakat. Tujuan dari penelitian ini yaitu mengetahui penerimaan yoghurt sari almond dengan penambahan kurma.

\section{METODE PENELITIAN}

Bahan yang digunakan pada pembuatan yoghurt sari almond dengan penambahan kurma ini, terdiri atas sari almond (Sanitarium, Australia), susu skim bubuk (Petit Eric, Indonesia), gula rendah kalori (Tropicana Slim, Indonesia), starter yoghurt (Biokul, Indonesia), dan kurma (Palm'frutt, Tunisia).

\section{Prosedur Penelitian}

Penelitian ini terdiri atas tiga tahap. Tahap pertama meliputi persiapan bahan dan peralatan serta penyusunan formula yoghurt sari almond dengan penambahan kurma. Tahap kedua yaitu proses pembuatan yoghurt sari almond dengan penambahan kurma. Tahap ketiga yaitu pelaksanaan uji hedonik dan uji peringkat. Persentase penambahan kurma pada pembuatan yoghurt sari almond yaitu sebanyak 10\%, 20\%, dan $30 \%$ dari berat sari almond. Persentase bahan yang digunakan data dilihat pada Tabel 1.

Proses pembuatan dimulai dengan buah kurma dipotong-potong kemudian dihancurkan bersama sari almond menggunakan blender (Maspion, Indonesia). Saring menggunakan kain saring nilon dengan gagang (Kazu KHL163, Indonesia) hingga diperoleh filtrat yang sudah bersih dari serat buah kurma. 
Tabel 1. Formula yoghurt sari almond dengan penambahan kurma

\begin{tabular}{lccc}
\hline \multirow{2}{*}{ Bahan } & \multicolumn{3}{c}{ Penambahan Kurma } \\
\cline { 2 - 4 } & F1 & F2 & F3 \\
\hline Sari almond $(\mathrm{mL})$ & 1.000 & 1.000 & 1.000 \\
Susu skim bubuk $(\%)$ & 5 & 5 & 5 \\
Gula rendah kalori $(\%)$ & 4 & 4 & 4 \\
Starter Yoghurt $(\%)$ & 4 & 4 & 4 \\
Kurma $(\%)$ & 10 & 20 & 30 \\
\hline
\end{tabular}

Tambahkan gula pasir dan susu skim bubuk pada filtrat, aduk hingga homogen. Filtrat kemudian dipasteurisasi menggunakan panci dengan suhu antara $60-63^{\circ} \mathrm{C}$ selama 30 menit. Suhu filtrat diturunkan hingga mencapai $43^{\circ} \mathrm{C}$, kemudian ditambahkan starter yogurt, lalu diinkubasi selama 6 jam menggunakan yogurt maker PA 102 (Yogurt Maker Machine, China). Setelah inkubasi, yoghurt sari almond kurma diaduk agar homogen.

Uji hedonik digunakan untuk memperoleh data penerimaan rasa, aroma, kekentalan, dan warna yoghurt sari almond dengan penambahan kurma. Jumlah panelis yang mengikuti uji hedonik dan mengisi kuesioner secara lengkap sebanyak 30 orang panelis tidak terlatih. Kuesioner yang digunakan, menggunakan 5 skala hedonik dengan kriteria yaitu sangat suka diberi nilai 5, suka diberi nilai 4, agak suka diberi nilai 3, tidak suka diberi nilai 2, dan sangat tidak suka diberi nilai 1 . Penilaian yang diberikan untuk uji hedonik dihitung secara rata-rata (mean), kemudian diberikan rentang interval intrepretasi terhadap hasil mean sebagai berikut (Suryono et al., 2018): 0,0-1,0 digolongkan sangat tidak suka; 1,1-2,0 digolongkan tidak suka; 2,1-3,0 digolongkan agak suka; 3,1-4,0 digolongkan suka; 4,1-5,0 digolongkan sangat suka.

Uji peringkat digunakan untuk mengetahui penerimaan umum panelis terhadap ketiga produk. Panelis diminta mengurutkan sampel yoghurt sari almond dengan penambahan kurma dari sampel yang paling disukai (peringkat 1) sampai yang paling tidak disukai (peringkat 3). Uji peringkat disimpulkan dengan melakukan penjumlahan setiap peringkat dari produk sampel.

\section{Analisis Data}

Data yang diperoleh dari hasil uji hedonik dianalisis menggunakan analisis nonparametrik yaitu uji Kruskal Wallis dan uji lanjut MannWhitney untuk mengetahui beda nyata antar kelompok. Hasil uji peringkat dianalisis secara deskriptif menggunakan Microsoft Excel 2019. Uji uji Kruskal Wallis dan uji lanjut Mann-Whitney menggunakan SPSS 25.0 for MacOS.

\section{HASIL DAN PEMBAHASAN}

Karakteristik panelis dapat diketahui dari jenis kelamin dan usia panelis. Berdasarkan jenis kelamin, panelis yang mengikuti uji hedonik sebanyak 20 orang panelis perempuan dan 10 orang panelis laki-laki. Berdasarkan tingkat usia, sebanyak 14 orang panelis berusia $\leq 20$ tahun, 7 orang panelis berusia 21-30 tahun, 3 orang panelis berusia 31-40 tahun dan sebanyak 6 orang panelis berusia $\geq 40$ tahun.

Hasil analisis data uji hedonik dengan menggunakan uji Kruskal Wallis dan uji lanjut Mann-Whitney dilihat pada Tabel 2. Hasil produk yoghurt sari almond dapat dilihat pada Gambar 1.

\section{Rasa}

Hasil uji hedonik rasa (Tabel 2) menunjukan panelis paling menyukai produk yoghurt sari almond dengan penambahan kurma sebanyak $30 \%$. Nilai rerata produk tersebut sebesar 3,83 $\pm 0,75$ dalam rentang nilai suka. Berdasarkan uji Kruskal Wallis $(p<0,05)$, artinya secara statistik menunjukkan nilai rerata penerimaan rasa antar ketiga produk yoghurt sari almond berbeda nyata. Hasil uji lanjut Mann-Whitney menunjukkan bahwa rasa dari yoghurt sari almond dengan penambahan kurma sebanyak $10 \%$ berbeda nyata dengan rasa yoghurt sari almond dengan penambahan kurma sebanyak $20 \%$ dan $30 \%$.

Tabel 2. Hasil uji hedonik rasa, aroma, kekentalan dan warna yoghurt sari almond dengan penambahan kurma

\begin{tabular}{ccccc}
\hline Persentase & \multicolumn{4}{c}{ Kategori } \\
\cline { 2 - 5 } Penambahan Kurma & Rasa & Aroma & Kekentalan & Warna \\
\hline $10 \%$ & $2,50 \pm 0,82 \mathrm{a}$ & $2,40 \pm 0,77 \mathrm{a}$ & $2,67 \pm 0,60 \mathrm{a}$ & $3,10 \pm 0,48 \mathrm{a}$ \\
$20 \%$ & $3,70 \pm 0,75 \mathrm{~b}$ & $3,40 \pm 0,77 \mathrm{~b}$ & $3,50 \pm 0,57 \mathrm{~b}$ & $3,90 \pm 0,66 \mathrm{~b}$ \\
$30 \%$ & $3,84 \pm 0,75 \mathrm{~b}$ & $3,23 \pm 0,73 \mathrm{~b}$ & $3,47 \pm 0,51 \mathrm{~b}$ & $3,97 \pm 0,62 \mathrm{~b}$ \\
\hline
\end{tabular}

Keterangan: Angka yang diikuti huruf yang sama menyatakan tidak berbeda nyata pada uji beda nyata $(\mathrm{p}=0,05)$ menurut uji Mann-Whitney. 


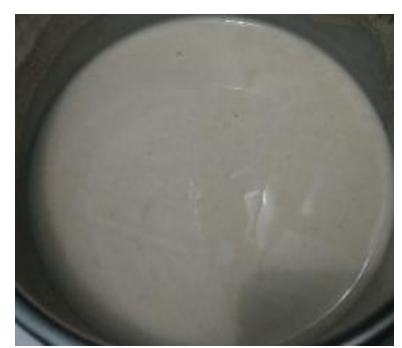

F1

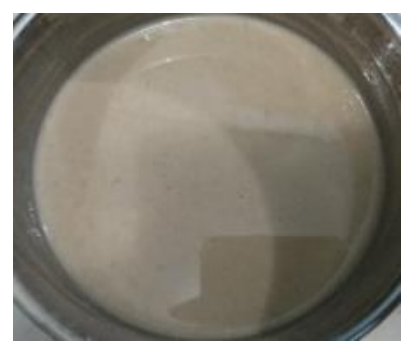

F2

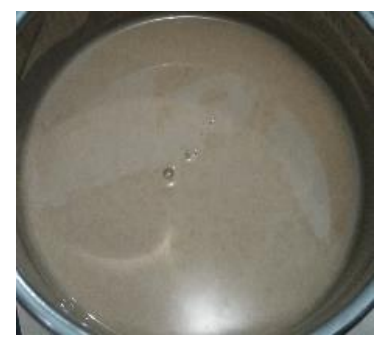

F3

Gambar 1. Yoghurt sari almond dengan jumlah penambahan kurma yang berbeda

Hal ini sejalan dengan hasil penelitian dari Balia et al. (2011) tentang yoghurt susu kambing dengan penambahan sari kurma. Hasil penelitian tersebut menyatakan bahwa penambahan sari kurma dapat memberikan rasa manis pada produk yoghurt susu kambing. Semakin sedikit jumlah kurma yang ditambahkan, menyebabkan yoghurt susu kambing berkurang rasa manisnya. Pada penelitian ini, rasa dari yoghurt sari almond dengan penambahan kurma sebanyak 30\% yaitu asam, manis, dan berasa kurma. Kombinasi dari ketiga rasa itulah yang disukai dan dapat diterima oleh panelis. Rasa manis dihasilkan dari penggunaan gula rendah kalori dan kurma. Rasa asam dihasilkan dari proses fermentasi oleh bakteri asam laktat.

\section{Aroma}

Hasil uji hedonik aroma menunjukkan produk yoghurt sari almond dengan penambahan kurma sebanyak $20 \%$ memiliki rerata tertinggi yaitu sebesar 3,40 \pm 0,77 dalam rentang nilai suka. Hasil uji Kruskal Wallis $(p<0,05)$ yang berarti ada perbedaan nyata dari nilai rerata penerimaan aroma ketiga produk yoghurt sari almond. Hasil uji lanjut Mann-Whitney menunjukkan bahwa aroma yoghurt sari almond dengan penambahan kurma sebanyak $10 \%$ berbeda nyata dengan aroma yoghurt sari almond dengan penambahan kurma sebanyak $20 \%$ dan $30 \%$.

Aroma yoghurt yang khas disebabkan oleh adanya komponen asam laktat, asetaldehid, asam propionat, asam butirat dan senyawa-senyawa volatil lain yang diproduksi selama proses fermentasi (Setiarto et al., 2017). Penelitian dari Nurminabari (2018) menyatakan aroma pada yoghurt sangat dipengaruhi oleh senyawa-senyawa volatil yang terkandung pada bahan baku atau senyawa volatil yang terbentuk selama proses fermentasi. Yoghurt sari almond dengan penambahan kurma sebanyak $20 \%$ memiliki aroma kurma dan aroma asam khas yoghurt. Semakin banyak penambahan kurma, produk yang dihasilkan sangat beraroma kurma. Semakin sedikit penambahan kurma, produk yang dihasilkan agak beraroma kurma.

\section{Kekentalan}

Hasil uji hedonik kekentalan pada Tabel 2 menunjukkan nilai rerata tertinggi pada produk yoghurt sari almond dengan penambahan kurma sebanyak $20 \%$. Nilai rerata yang dihasilkan yaitu

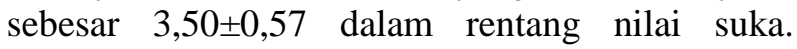
Berdasarkan hasil uji Kruskal Wallis $(p<0,05)$, artinya dari ketiga produk terdapat perbedaan nyata untuk nilai rerata penerimaan kekentalan yoghurt sari almond. Hasil uji lanjut Mann-Whitney menunjukkan kekentalan yoghurt sari almond dengan penambahan kurma sebanyak $10 \%$ berbeda nyata dengan kekentalan yoghurt sari almond dengan penambahan kurma sebanyak $20 \%$ dan $30 \%$.

Yoghurt sari almond dengan penambahan kurma sebanyak $20 \%$ memiliki tekstur yang agak kental dan homogen. Semakin sedikit penambahan kurma, yoghurt yang dihasilkan tidak kental. Semakin banyak penambahan kurma, yoghurt yang dihasilkan menjadi kental. Meskipun telah dilakukan penyaringan untuk memisahkan filtrat dan residu serat kurma, filtrat yang dihasilkan tetap lebih kental. Hal ini dapat disebabkan karena kandungan serat dan karbohidrat dalam kurma (Berlianita et al., 2021). Pada penelitian ini, penambahan jumlah kurma tidak disertai dengan penambahan jumlah sari almond.

\section{Warna}

Berdasarkan uji hedonik warna pada Tabel 2, produk yoghurt sari almond dengan penambahan kurma sebanyak 30\% memiliki rerata tertinggi

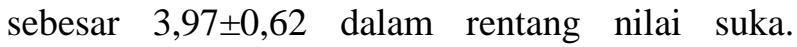
Penerimaan warna yoghurt sari almond pada uji Kruskal Wallis $(p<0,05)$ yang berarti terdapat perbedaan nilai rerata penerimaan warna antar 
produk yoghurt sari almond. Hasil uji lanjut MannWhitney menunjukkan warna yoghurt sari almond dengan penambahan kurma sebanyak $10 \%$ berbeda nyata dengan warna yoghurt sari almond dengan penambahan kurma sebanyak $20 \%$ dan $30 \%$.

Hal ini sesuai dengan hasil penelitian sebelumnya tentang soyghurt dengan penambahan jus kurma. Penelitian tersebut menyatakan bahwa perbedaan formulasi jus kurma dan sari kedelai menghasilkan warna coklat dari jus kurma pada produk soyghurt (Purwanto et al., 2018). Menurut Agustin (2018), warna cokelat buah kurma disebabkan karena kandungan tannin dalam kurma. Pada penelitian ini, produk yoghurt sari almond dengan penambahan kurma sebanyak 30\% memiliki warna cokelat. Warna cokelat yang dihasilkan karena penggunaan kurma dalam jumlah yang banyak. Semakin sedikit penambahan kurma akan menghasilkan warna agak cokelat dan tidak cokelat.

\section{Uji Peringkat}

Penerimaan secara umum dari ketiga produk menghasilkan data yaitu sebanyak $57 \%$ panelis memilih yoghurt sari almond dengan penambahan kurma sebanyak 30\% sebagai peringkat 1 atau sebagai produk yang paling disukai. Sebagai peringkat 3 atau paling tidak disukai yaitu yoghurt sari almond dengan penambahan kurma sebanyak $10 \%$. Hal ini membuktikan bahwa produk yoghurt sari almond dengan penambahan kurma sebanyak $30 \%$ merupakan produk terbaik yang dapat diterima oleh panelis.

\section{KESIMPULAN}

Berdasarkan penelitian ini, maka dapat disimpulkan bahwa penambahan kurma dapat meningkatkan penerimaan rasa, aroma, kekentalan, dan warna yoghurt sari almond. Penambahan kurma pada pembuatan yoghurt sari almond ini dapat menjadi rujukan inovasi produk pangan baru yang dapat diterima masyarakat. Perlu dilakukan penelitian lanjut untuk mengetahui kandungan gizi dari yoghurt sari almond dengan penambahan kurma.

\section{DAFTAR PUSTAKA}

Agustin, C. 2018. Formulasi Es Krim Sari Kurma. Jurnal Riset Kesehatan Poltekkes Depkes Bandung 10: 25. DOI: 10.34011/ juriskesbdg.v10i1.113

Arisanti, D. dan S. Al. Islamiyah. 2017. Efektivitas
Penambahan Ekstrak Kurma terhadap Karakteristik Gizi Fruitghurt. JTech 8: 135139.

Astrini, S., I. Wahyuni, dan B. Widjasena. 2017. Perbedaan pemberian kurma (Phoenix dactylifera) terhadap kelelahan kerja pada pekerja bagian finishing di PT. PP (Persero) Tbk. Jurnal Kesehatan Masyarakat 41: 84-93.

Balia, R.L., H. Chairunnisa, O. Rachmawan, dan E. Wulandari. 2011. Derajat keasaman dan karakteristik organoleptik produk fermentasi susu kambing dengan penambahan sari kurmayang diinokulasikan berbagai kombinasi starter bakteri asam laktat. Jurnal Ilmu Ternak Universitas Padjadjaran 11: 4952.

Berlianita, I.T., D. Kristiastuti, A. Sutiadiningsih, dan M.G. Miranti. 2021. Pengaruh penambahan sari kurma (Phoenix dactylifera) dan sari temulawak (Curcuma zanthorrhiza) terhadap sifat organoleptik jelly drink. Jurnal Tata Boga 10: 175-184.

Lubis, S.A. dan G. Anjani. 2016. Aktivitas antioksidan, total bakteri asam laktat, sifat fisik dan tingkat penerimaan yoghurt almond (Prunus dulcis) sebagai produk probiotik alternatif bagi penderita autis. Journal of Nutrition College 5: 334-343.

Nath, M., A. Tasnim, J.M.K.H. Chowdhury, and F. Alam. 2020. Comprehensive evaluations of physicochemical characteristics and sensory acceptance of selected fruits, almond and dark chocolate incorporated yogurt. Journal of Food and Agriculture 13: 20-36.

Nurminabari, I.S. 2018. Kajian penambahan skim dan santan terhadap karakteristik yoghurt dari whey. Pasundan Food Technology Journal 5: 54. DOI: $10.23969 /$ pftj.v5i1.810.

Purwanto, T., S. Nurohmi, A. Rahadiyanti, dan M.D. Naufalina. 2018. Analisis daya terima yogurt sari kedelai (Soygurt) dengan penambahan jus kurma (Phoenix dactylifera). Darussalam Nutrition Journal 2: 39. DOI: 10.21111/dnj.v2i1.1982

Retnowati, P.A. dan J. Kusnadi. 2014. Pembuatan minuman probiotik sari buah kurma (Phoneix dactylifera) dengan isolat Lactobacillus casei dan Lactobacillus plantarum. Jurnal Pangan dan Agroindustri 2: 70-81.

Rusilawati, M.N. 2019. Pengaruh perbandingan sari almond (Prunus dulcis) dengan susu skim dan lama fermentasi terhadap karakteristik yoghurt sari almond. Universitas Pasundan.

Setiarto, R.H.B., N. Widhyastuti, dan I. Fairuz. 
2017. Pengaruh starter bakteri asam laktat dan penambahan tepung talas termodifikasi terhadap kualitas yogurt sinbiotik. Jurnal Riset Teknologi Industri 11: 18-30.

Simatupang, L.F., R.J. Nainggolan, dan M. Nurminah. 2018. Pengaruh perbandingan sari kurma (Phoenix dactylifera) dengan sari kecombrang (Etlingera elatior) dan penambahan gula aren terhadap mutu minuman sari kumbrang. Jurnal Rekayasa
Pangan dan Pertanian 6: 264-272.

Suryono, C., L. Ningrum, dan T.R. Dewi. 2018. Uji kesukaan dan organoleptik terhadap 5 kemasan dan produk Kepulauan Seribu secara deskriptif. Jurnal Pariwisata 5: 95-106.

Syainah, E., S. Novita, dan R. Yanti. 2014. Kajian pembuatan yoghurt dari berbagai jenis susu dan inkubasi yang berbeda terhadap mutu dan daya terima. Skala Kesehatan 5: 48-58. 